\title{
Influence of Temperature on Wax Deposit on Corrosion of Crude Oil Pipeline
}

\author{
Nnorom Obinichi ${ }^{1,}$, , Alexander Nwachukwu Okpala ${ }^{2}$, Tolumoye Johnnie Tuaweri ${ }^{3}$ \\ ${ }^{1}$ Mechanical Engineering, University of Port Harcourt, Choba, Port Harcourt, Nigeria \\ ${ }^{2}$ Mechanical Engineering, Niger Delta University, Wilberforce Island, Nigeria \\ ${ }^{3}$ Mechanical Engineering, Nigeria Maritime University, Okerenkoko, Nigeria
}

Email address:

obinichi.nnorom@uniport.edu.ng (N. Obinichi)

${ }^{*}$ Corresponding author

\section{To cite this article:}

Nnorom Obinichi, Alexander Nwachukwu Okpala, Tolumoye Johnnie Tuaweri. Influence of Temperature on Wax Deposit on Corrosion of Crude Oil Pipeline. American Journal of Mechanical and Materials Engineering. Vol. 5, No. 2, 2021, pp. 29-34.

doi: 10.11648/j.ajmme.20210502.12

Received: May 25, 2021; Accepted: June 11, 2021; Published: June 25, 2021

\begin{abstract}
The paper aims to study the effect of temperature on wax deposition on corrosion of crude oil pipeline at different flow rate with time. The waxy crude oil sample is pumped into the design and fabricated experimental flow-loop set up under different operating conditions. The effect of temperature on corrosion at different flow rate of wax deposition during the corrosion inhibition were studied at flow rate of $10.21,20.37,30.45,40.28$ and $50.70 \mathrm{~L} / \mathrm{min}$ and time at $3,6,9,12,15$ and 18 min while keeping temperature constant for each of the experimental run at $15,20,25,30$ and $35^{\circ} \mathrm{C}$, to determine the corrosion rate against time. The results showed that at flow rate of $10.21 \mathrm{~L} / \mathrm{min}$ and time $18 \mathrm{~min}$ at constant temperature of $15^{\circ} \mathrm{C}$, the corrosion rate is $0.11 \mathrm{mpy}$. At flow rate of $10.21 \mathrm{~L} / \mathrm{min}$ and time $18 \mathrm{~min}$ at constant temperature of $20^{\circ} \mathrm{C}$, the corrosion rate is $0.08 \mathrm{mpy}$. At flow rate of $10.21 \mathrm{~L} / \mathrm{min}$ and time $18 \mathrm{~min}$ at constant temperature of $25^{\circ} \mathrm{C}$, the, corrosion rate is $0.12 \mathrm{mpy}$. Based on the results, a significant reduction of corrosion rates and excellent corrosion protection is achieved while others provided only moderate or negligible protection to the crude oil pipeline. However, the wax layer becomes thicker with time, if the temperature stays below the WAT for extended period of time and can in the long run, cause partial or total blockage of the pipe. Hence, as the deposition of the paraffin wax increases the corrosion rate decrease. The paraffin wax film presence on the surface promotes a significant reduction of general corrosion rates on the pipeline, although localized corrosion was observed due to loss of integrity of the paraffin layer. It means that deposition of paraffin wax inhibit corrosion and also give protection to the pipeline layer. Finally, due to the long chain paraffin layer being physically removed from the surface most of the corrosion protection has been lost during the periods of increased flow rate or temperature.
\end{abstract}

Keywords: Temperature, Wax Deposition, Corrosion Rate

\section{Introduction}

Paraffin wax deposition is one of the long standing problems in the oil industry, Crude oils often contain paraffin which precipitate and adhere to the tubing, sucker rods, liner and surface equipment as the temperature of the producing stream decreases in the normal course of flowing, pumping or gas lifting. Heavy paraffin deposits are undesirable because they restrict the production rate from the well and reduce the effective size of the flow conduits [1]. Where severe paraffin deposition occurs, removal of the deposits by thermal, mechanical, or other means is required, resulting in costly down time and increased operating costs.

Treatments designed to remove waxy deposits significant operating costs are incurred from production tubing or squeeze treatments designed to inhibit wax deposition [1]. The costs are increased further by formation damage and loss of production that may result from these treatments. Paraffin deposition may occur also in the producing formation, under certain conditions. Some of the problems caused by these deposits are related to flow restriction, which leads to pressure increase in the flow line, decrease in production, and problems of mechanical [2]. 
Corrosion in steel pipelines is a major problem that is face by petroleum industries. A common problem face by the industry is the presence of water and microbiological species which cause corrosion. The usage of corrosion resistant alloys (CRAs) has to be excluded because of high cost. On the other hand, Because of minimal effort, simple manufacturing and conveniences in using, carbon steel is widely used in the industry [2]. However, due to internal corrosion the pipelines lifespan is reduced. A study conducted by National Association of Corrosion Engineers International, which has estimated that the total cost of corrosion in the oil and gas industry is $\$ 1.327$ billion annually which includes $\$ 589$ million of direct cost in the surface pipeline and facility cost [3]. In that, great portion is due to internal corrosion in transportation utilities. Thus, in order to diminish the loss brought on by internal corrosion, it is important to study the occurrences of internal pipeline corrosion more intense and reduce the aspects that induce it.

Paraffin wax acts as a corrosion inhibitor by covering the inner wall of pipeline, but they restrict flow in the pipeline. Many problems in oil and gas industry are being caused by paraffin wax and $\mathrm{CO}_{2}$ corrosion. These problems mainly caused in the transportation and utilities where the pipelines are severely corroded. The paraffin wax on the surface provide excellent corrosion protection, while others provided only moderate or negligible protection in the crude oil pipeline, but due to the long chain paraffin layer being physically removed from the surface most of the corrosion protection has been lost during the periods of increased temperature or increased flow rates [4]. The protection of paraffin can be assumed to be due to physisorption caused by relatively weak intermolecular forces such as van der Waals forces. At low temperatures-below the so called wax appearance temperature (WAT), paraffin can precipitate and deposit on the pipe surface despite the lack of surface chemical activity. When the wax layer covers the steel surface it can slow down corrosion processes by hindering the diffusion of corrosive species to the surface. The wax layer becomes thicker with time, and can, in the long run, cause partial or total blockage of the pipe, if the temperature stays below the WAT for extended period of time. Corrosion inhibition can be generated from crude oils, but the extent of inhibition varied from one crude oil to another. When it comes to corrosion of carbon steels in the oil industry, the main reason for its occurrence, is the presence of dissolved carbon dioxide $\mathrm{CO}_{2}$ (sweet corrosion), hydrogen sulfide $\mathrm{H}_{2} \mathrm{~S}$ (sour corrosion) and oxygen in the oil, and sodium chloride dissolved in water injections, and due to the use of acids during the oil and gas well acidizing $[15,16,13,8]$. In other industries, corrosion occurs for example, during the materials acidization using acid solutions in pickling processes, during the industrial acid cleaning, in various aqueous electrolyte storage tanks, in boilers, and during the removal of rust, scale and corrosion products $[9,14,6,10]$. Removal of any one of the above mentioned corrosion factors (anode/cathode surface sites, electrolyte) results in the termination of the electrochemical corrosion process.
Unfortunately, in reality, it is impossible to fully achieve this, but there exist methods of reducing the influence of one or more of these factors, and thus reducing the kinetics of the corrosion process, i.e. decreasing (slowing down) the corrosion rate. Corrosion inhibition is the most common way of mitigating the internal-walls corrosion in industrial facilities (pipelines, tanks, reactors, etc). Most of the well-known corrosion inhibitors are organic compounds containing nitrogen, sulfur and/or oxygen atoms $[5,7]$. Pipelines are central to the global oil and gas industry because of their significant in transporting oil and natural gas from upstream production to downstream refineries, power stations and markets, across nations, oceans and continents [11]. The Department of Homeland Security (DHS), USA describes pipelines systems as critical transportation infrastructures because they deliver about two thirds of America's energy needs, and they are essential to both standards of living and economies [12]. The paper aims to study the influence of temperature on wax deposition on corrosion of crude oil pipeline and the results obtained are presented.

\section{Materials and Methods}

\subsection{Materials}

An experimental laboratory flow loop were designed and fabricated which can give a better scenario of crude oil pipeline and accurate result to investigate the effect of temperature on corrosion of crude oil pipeline are shown in Figure 1. Other materials used are waxy crude oil, a $0.5 \mathrm{hp}$ pump for re-circulating the waxy crude oil, flow meter with a temperature probe, electronic weighing balance, electric cooker, ball valves for regulating the flow of the fluid, handheld infrared thermometer for temperature measurement and MS1000 Corrosion Meter to measure the corrosion rate against time in the crude oil pipeline.

\subsection{Methods}

To study the effect of temperature on corrosion of crude oil pipeline, the waxy crude oil sample is pumped into the flowloop set up under different operating conditions. The range of the inlet temperature of the waxy crude oil was $\left(10-40^{\circ} \mathrm{C}\right)$. The experiment was conducted 5 times, at time interval of 3 18 minutes, temperature were varied between $15-35^{\circ} \mathrm{C}$ and flow rate were also varied between $10.21-50.70 \mathrm{~L} / \mathrm{min}$. The experiment was carried out at varying flow rate with time while temperature was kept constant. At flow rate of 10.21 , $20.37,30.45,40.28$ and $50.70 \mathrm{~L} / \mathrm{min}$ and at time of $3,6,9,12$, 15 and 18 min while keeping temperature constant for each of the experimental run at $15,20,25,30$ and $35^{\circ} \mathrm{C}$ to determine the corrosion rate against time. After testing the corrosion rate against time of the waxy crude oil to ascertain the effect of temperature at varying flow rate and time of the paraffin wax deposited on the crude oil pipeline. The results were recorded, the graph of corrosion rate (mpy) against time (min) was plotted and the results were analyzed. 


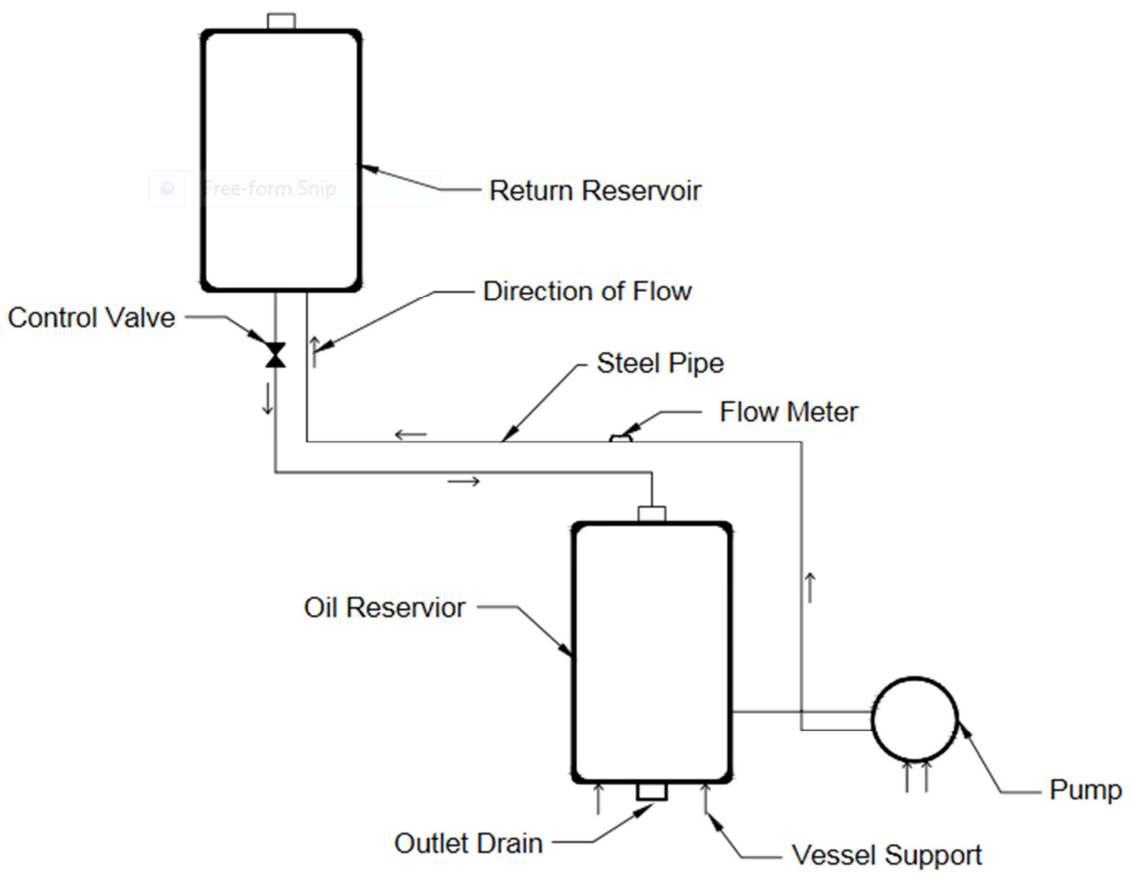

Figure 1. Schematic Diagram of the Experimental Laboratory Flow Loop.

\section{Results and Discussion}

Tables 1 to 3 and figures 1 to 3 illustrates the effect of temperature on wax deposition on corrosion of crude oil pipeline which were examined and the results were documented.

The effect of temperature on wax deposition on corrosion of crude oil pipeline were investigated at varying flow rate with time while keeping temperature constant for each of the experiment and the results obtained were analyzed using tables 1-3 and figures 1-3. The effect of temperature on corrosion at different flow rate of wax deposition during the corrosion inhibition were studied at flow rate of 10.21, 20.37, $30.45,40.28$ and $50.70 \mathrm{~L} / \mathrm{min}$ and time at $3,6,9,12,15$ and 18 min while keeping temperature constant for each of the experimental run at $15,20,25,30$ and $35^{\circ} \mathrm{C}$, to determine the corrosion rate against time. Based on the results of table 1 , at flow rate of $10.21 \mathrm{~L} / \mathrm{min}$ and time $18 \mathrm{~min}$ at constant temperature of $15^{\circ} \mathrm{C}$, a significant reduction of corrosion rates and excellent corrosion protection is achieved while others provided only moderate or negligible protection to the crude oil pipeline.

Table 1. Effect of Temperature at $15^{\circ} \mathrm{C}$ on Corrosion Rate against Time on Wax Deposition.

\begin{tabular}{|c|c|c|c|c|c|}
\hline $\begin{array}{l}\text { Time } \\
\text { (min) }\end{array}$ & $\begin{array}{l}\text { Corrosion Rate (mpy) } \\
\text { @ } 10.21 \mathrm{~L} / \mathrm{min}\end{array}$ & $\begin{array}{l}\text { Corrosion Rate (mpy) @ } \\
20.37 \mathrm{~L} / \mathrm{min}\end{array}$ & $\begin{array}{l}\text { Corrosion Rate (mpy)@ } \\
\text { 30.45L/min }\end{array}$ & $\begin{array}{l}\text { Corrosion Rate (mpy) @ } \\
40.28 \mathrm{~L} / \mathrm{min}\end{array}$ & $\begin{array}{l}\text { Corrosion Rate (mpy)@ } \\
50.70 \text { L/min }\end{array}$ \\
\hline 3 & 0.65 & 0.53 & 0.39 & 0.56 & 0.48 \\
\hline 6 & 0.41 & 0.48 & 0.55 & 0.79 & 0.52 \\
\hline 12 & 0.21 & 0.29 & 0.44 & 0.61 & 0.49 \\
\hline 15 & 0.16 & 0.22 & 0.32 & 0.47 & 0.66 \\
\hline 18 & 0.11 & 0.14 & 0.45 & 0.54 & 0.43 \\
\hline
\end{tabular}

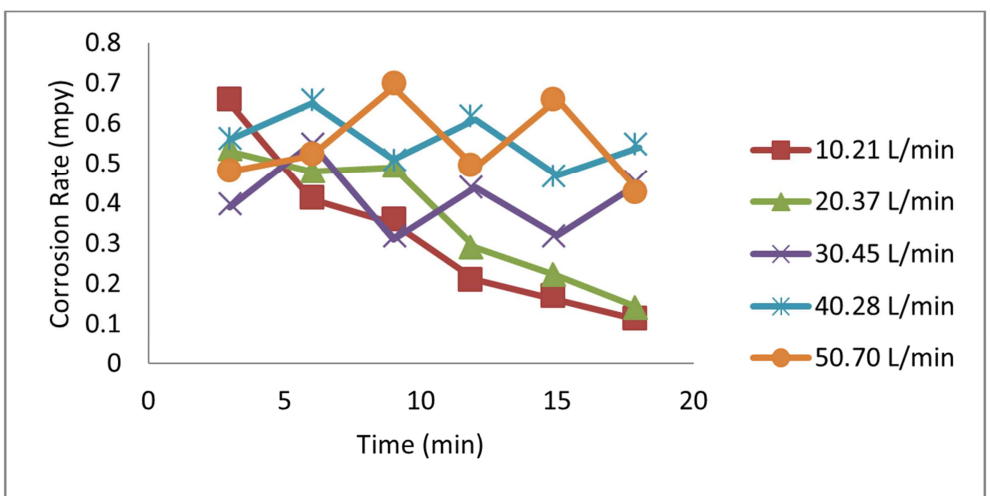

Figure 1. Graph of the Effect of Temperature at $15^{\circ} \mathrm{C}$ on Corrosion Rate against Time on Wax Deposition. 
Table 2. Effect of Temperature at $20^{\circ} \mathrm{C}$ on Corrosion Rate against Time on Wax Deposition.

\begin{tabular}{llllll}
\hline $\begin{array}{l}\text { Time } \\
(\mathbf{m i n})\end{array}$ & $\begin{array}{l}\text { Corrosion Rate } \\
(\mathbf{m p y}) @ \mathbf{1 0 . 2 1} \mathbf{L} / \mathbf{m i n}\end{array}$ & $\begin{array}{l}\text { Corrosion Rate (mpy) @ } \\
\mathbf{2 0 . 3 7 L} / \mathbf{m i n}\end{array}$ & $\begin{array}{l}\text { Corrosion Rate (mpy) @ } \\
\mathbf{3 0 . 4 5 L} / \mathbf{m i n}\end{array}$ & $\begin{array}{l}\text { Corrosion Rate (mpy) @ } \\
\mathbf{4 0 . 2 8} \mathbf{L} / \mathbf{m i n}\end{array}$ & $\begin{array}{l}\text { Corrosion Rate (mpy) @ } \\
\mathbf{5 0 . 7 0} \mathbf{L} / \mathbf{m i n}\end{array}$ \\
\hline 3 & 0.31 & 0.69 & 0.51 & 0.41 & 0.71 \\
6 & 0.42 & 0.51 & 0.46 & 0.52 & 0.66 \\
9 & 0.21 & 0.61 & 0.31 & 0.45 & 0.51 \\
12 & 0.29 & 0.36 & 0.16 & 0.26 & 0.43 \\
15 & 0.19 & 0.17 & 0.22 & 0.44 & 0.55 \\
18 & 0.08 & 0.12 & 0.31 & 0.25 & 0.39 \\
\hline
\end{tabular}

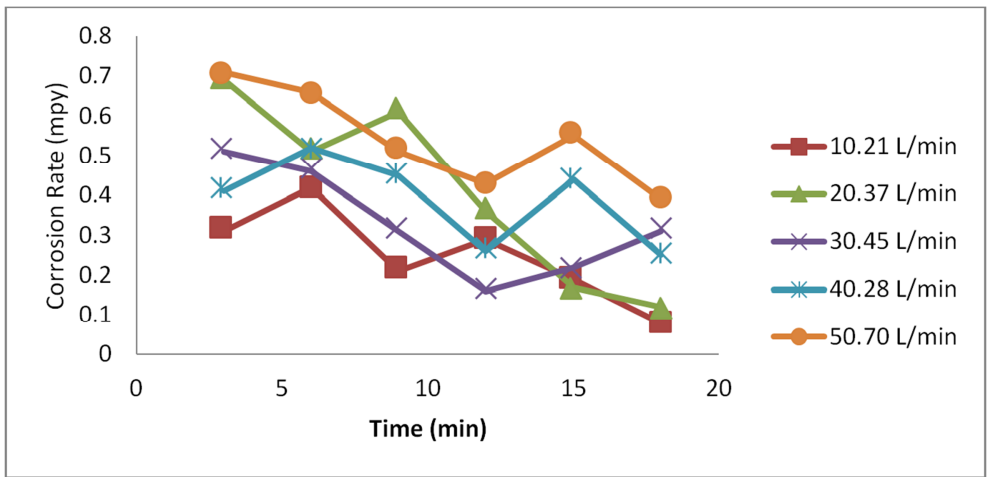

Figure 2. Graph of the Effect of Temperature at $20^{\circ} \mathrm{C}$ on Corrosion Rate against Time on Wax Deposition.

Table 3. Effect of Temperature at $25^{\circ} \mathrm{C}$ on Corrosion Rate against Time on Wax Deposition.

\begin{tabular}{|c|c|c|c|c|c|}
\hline $\begin{array}{l}\text { Time } \\
(\mathrm{min})\end{array}$ & $\begin{array}{l}\text { Corrosion Rate } \\
(\mathrm{mpy}) @ 10.21 \mathrm{~L} / \mathrm{min}\end{array}$ & $\begin{array}{l}\text { Corrosion Rate (mpy) @ } \\
20.37 \mathrm{~L} / \mathrm{min}\end{array}$ & $\begin{array}{l}\text { Corrosion Rate (mpy) @ } \\
\text { 30.45L/min }\end{array}$ & $\begin{array}{l}\text { Corrosion Rate (mpy) @ } \\
\mathbf{4 0 . 2 8 ~ L / m i n ~}\end{array}$ & $\begin{array}{l}\text { Corrosion Rate (mpy)@ } \\
50.70 \text { L/min } \\
\end{array}$ \\
\hline 3 & 0.48 & 0.58 & 0.62 & 0.51 & 0.73 \\
\hline 6 & 0.56 & 0.67 & 0.38 & 0.43 & 0.82 \\
\hline 9 & 0.36 & 0.52 & 0.49 & 0.62 & 0.56 \\
\hline 12 & 0.28 & 0.41 & 0.56 & 0.24 & 0.74 \\
\hline 15 & 0.18 & 0.23 & 0.32 & 0.52 & 0.34 \\
\hline 18 & 0.12 & 0.30 & 0.25 & 0.35 & 0.61 \\
\hline
\end{tabular}

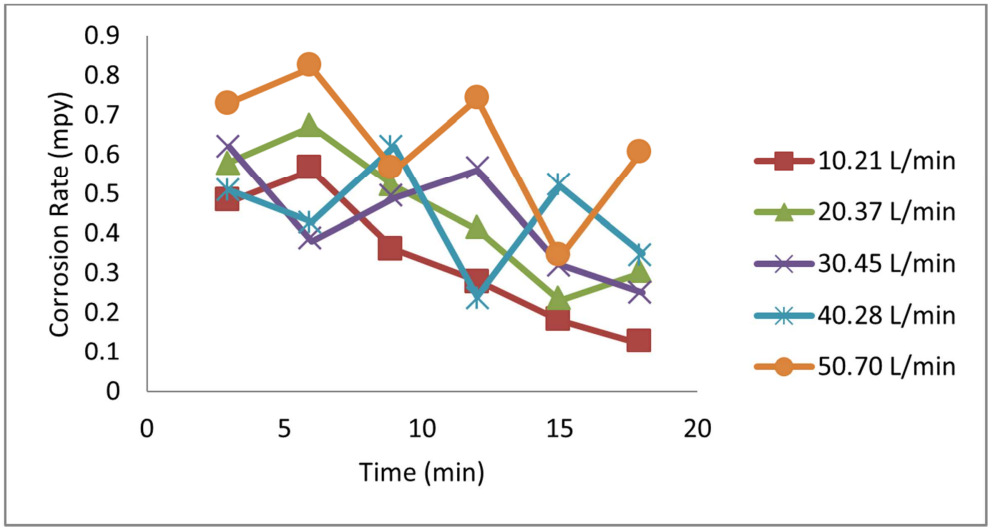

Figure 3. Graph of the Effect of Temperature at $25^{\circ} \mathrm{C}$ on Corrosion Rate against Time on Wax Deposition.

However, the wax layer becomes thicker with time, if the temperature stays below the WAT for extended period of time and can, in the long run, cause total or partial blockage of the pipe.

It was observed that at time $3 \mathrm{~min}$ and at flow rate of 10.21 $\mathrm{L} / \mathrm{min}$, the corrosion rate is $0.65 \mathrm{mpy}$ and $0.53 \mathrm{mpy}$ at 20.37 $\mathrm{L} / \mathrm{min}$ at the same time, $0.39 \mathrm{mpy}$ at the same time and flow rate of $30.45 \mathrm{~L} / \mathrm{min}, 0.56 \mathrm{mpy}$ at flow rate of $40.28 \mathrm{~L} / \mathrm{min}$, and $0.48 \mathrm{mpy}$ at flow rate of $50.70 \mathrm{~L} / \mathrm{min}$. At time $6 \mathrm{~min}$ and flow rate of $10.21 \mathrm{~L} / \mathrm{min}, 20.37 \mathrm{~L} / \mathrm{min}, 30.45 \mathrm{~L} / \mathrm{min}, 40.28$ $\mathrm{L} / \mathrm{min}, 50.70 \mathrm{~L} / \mathrm{min}$ the corrosion rate were $0.41 \mathrm{mpy}, 0.48$ mpy, $0.55 \mathrm{mpy}, 0.79 \mathrm{mpy}$, and $0.52 \mathrm{mpy}$ respectively. At time $9 \mathrm{~min}$ corrosion rate were $0.35 \mathrm{mpy}, 0.49 \mathrm{mpy}, 0.31$ mpy, $0.51 \mathrm{mpy}$, and $0.69 \mathrm{mpy}$ in the order of the flow rates respectively. At time $12 \mathrm{~min}$ in the order of the flow rates, corrosion rate were $0.21 \mathrm{mpy}, 0.29 \mathrm{mpy}, 0.44 \mathrm{mpy}, 0.61 \mathrm{mpy}$, and $0.49 \mathrm{mpy}$ respectively. At time $15 \mathrm{~min}$ corrosion rate were $0.16 \mathrm{mpy}, 0.22 \mathrm{mpy}, 0.32 \mathrm{mpy}, 0.47 \mathrm{mpy}$, and 0.66 mpy in the order of the flow rates respectively and at $18 \mathrm{~min}$ the corrosion rate were $0.11 \mathrm{mpy}, 0.14 \mathrm{mpy}, 0.45 \mathrm{mpy}, 0.54$ mpy, and 0.43 mpy respectively.

Based on the experimental results of table 2, at flow rate of 
10.21 L/min and time $18 \mathrm{~min}$ at constant temperature of $20^{\circ} \mathrm{C}$, a significant reduction of corrosion rates and excellent corrosion protection is achieved while others provided only moderate or negligible protection to the crude oil pipeline.

However, the wax layer becomes thicker with time, if the temperature stays below the WAT for extended period of time and can, in the long run, cause total or partial blockage of the pipe.

It was observed that at time $3 \mathrm{~min}$ and at flow rate of 10.21 $\mathrm{L} / \mathrm{min}$, the corrosion rate is $0.31 \mathrm{mpy}$ and $0.69 \mathrm{mpy}$ at 20.37 $\mathrm{L} / \mathrm{min}$ at the same time, $0.51 \mathrm{mpy}$ at the same time and flow rate of $30.45 \mathrm{~L} / \mathrm{min}, 0.41 \mathrm{mpy}$ at flow rate of $40.28 \mathrm{~L} / \mathrm{min}$, and $0.71 \mathrm{mpy}$ at flow rate of $50.70 \mathrm{~L} / \mathrm{min}$. At time $6 \mathrm{~min}$ and flow rate of $10.21 \mathrm{~L} / \mathrm{min}, 20.37 \mathrm{~L} / \mathrm{min}, 30.45 \mathrm{~L} / \mathrm{min}, 40.28$ $\mathrm{L} / \mathrm{min}, 50.70 \mathrm{~L} / \mathrm{min}$ the corrosion rate were $0.42 \mathrm{mpy}, 0.51$ mpy, $0.46 \mathrm{mpy}, 0.52 \mathrm{mpy}$, and $0.66 \mathrm{mpy}$ respectively. At time 9 min corrosion rate were $0.21 \mathrm{mpy}, 0.61 \mathrm{mpy}, 0.31$ mpy, $0.45 \mathrm{mpy}$, and $0.51 \mathrm{mpy}$ in the order of the flow rates respectively. At time $12 \mathrm{~min}$ in the order of the flow rates were $0.29 \mathrm{mpy}, 0.36 \mathrm{mpy}, 0.16 \mathrm{mpy}, 0.26 \mathrm{mpy}$, and 0.43 mpy respectively. At time $15 \mathrm{~min}$ corrosion rate were 0.19 mpy, $0.17 \mathrm{mpy}, 0.22 \mathrm{mpy}, 0.44 \mathrm{mpy}$, and $0.55 \mathrm{mpy}$ in the order of the flow rates respectively and at $18 \mathrm{~min}$ the corrosion rate were $0.08 \mathrm{mpy}, 0.12 \mathrm{mpy}, 0.31 \mathrm{mpy}, 0.25 \mathrm{mpy}$, and finally ending at 0.39 mpy respectively.

Based on the experimental results of table 3 , at flow rate of $10.21 \mathrm{~L} / \mathrm{min}$ and time $18 \mathrm{~min}$ at constant temperature of $25^{\circ} \mathrm{C}$, a significant reduction of corrosion rates and excellent corrosion protection is achieved while others provided only moderate or negligible protection to the crude oil pipeline.

The wax layer becomes thicker with time, and can, in the long run, cause partial or total blockage of the pipe, if the temperature stays below the WAT for extended period of time.

It was observed that at time $3 \mathrm{~min}$ and at flow rate of 10.21 $\mathrm{L} / \mathrm{min}$, the corrosion rate is $0.48 \mathrm{mpy}$ and $0.58 \mathrm{mpy}$ at 20.37 $\mathrm{L} / \mathrm{min}$ at the same time, $0.62 \mathrm{mpy}$ at the same time and flow rate of $30.45 \mathrm{~L} / \mathrm{min}, 0.51 \mathrm{mpy}$ at flow rate of $40.28 \mathrm{~L} / \mathrm{min}$, and $0.73 \mathrm{mpy}$ at flow rate of $50.70 \mathrm{~L} / \mathrm{min}$. At time $6 \mathrm{~min}$ and flow rate of $10.21 \mathrm{~L} / \mathrm{min}, 20.37 \mathrm{~L} / \mathrm{min}, 30.45 \mathrm{~L} / \mathrm{min}, 40.28$ $\mathrm{L} / \mathrm{min}, 50.70 \mathrm{~L} / \mathrm{min}$ the corrosion rate were $0.56 \mathrm{mpy}, 0.67$ mpy, $0.38 \mathrm{mpy}, 0.43 \mathrm{mpy}$, and $0.82 \mathrm{mpy}$ respectively. At time $9 \mathrm{~min}$ corrosion rate were $0.36 \mathrm{mpy}, 0.52 \mathrm{mpy}, 0.49$ mpy, $0.62 \mathrm{mpy}$, and $0.56 \mathrm{mpy}$ in the order of the flow rates respectively. At time $12 \mathrm{~min}$ in the order of the flow rates were $0.28 \mathrm{mpy}, 0.41 \mathrm{mpy}, 0.56 \mathrm{mpy}, 0.24 \mathrm{mpy}$, and 0.74 mpy respectively. At time $15 \mathrm{~min}$ corrosion rate were 0.18 mpy, $0.23 \mathrm{mpy}, 0.32 \mathrm{mpy}, 0.52 \mathrm{mpy}$, and $0.34 \mathrm{mpy}$ in the order of the flow rates respectively and at $18 \mathrm{~min}$ the corrosion rate were $0.12 \mathrm{mpy}, 0.30 \mathrm{mpy}, 0.25 \mathrm{mpy}, 0.35 \mathrm{mpy}$, and finally ending at 0.61 mpy respectively.

These results are in good agreement and can be correlated with previous investigations reported by $[18,22]$. These set of results dealt with the amount of wax deposition as a dependent of flow rate, temperature or its equivalent production rate of waxy crude oil in the corrosion of pipeline. [17] Hypothesized that a higher flow shear, which is a function of flow rate and temperature, leads to lesser but likely harder deposit build up which will provide excellent corrosion protection to the crude oil pipeline. Thus wax deposition gradually decreases with increase in flow rate or temperature and corrosion protection will be lost in the crude oil pipeline.

This results is in total agreement with previous studies conducted by $[20,19,21]$, but however, disagreed experimentally that wax deposition would increase by increasing temperature between the pipe wall as reported by [23, 24].

The protection of paraffin can be assumed to be due to physisorption caused by relatively weak intermolecular forces such as van der Waals forces. [4] Found that paraffin wax film presence on the surface promotes a significant reduction of general corrosion rates, although localized corrosion was observes relating to loss of integrity of the paraffin layer.

Finally, due to the long chain paraffin layer being physically removed from the surface most of the corrosion protection has been lost during the periods of increased flow rate or temperature.

\section{Conclusion}

Wax deposition and $\mathrm{CO}_{2}$ corrosion are long standing problem in the oil and gas industry. At temperatures below the Wax Appearance Temperature paraffin wax layers can provide a substantial corrosion protection. However, since they interact weakly with the metal surface by van der Waals interactions they should not be counted upon for corrosion protection and can be removed with heat and/or shear possibly resulting in a localized attack on the steel surface. Heavy paraffin deposits are undesirable, because they reduce the effective size of the flow conduits and restrict the production rate from the well. Factors that are causing the wax formation are the temperature, flow rate and concentration. Carbon dioxide corrosion on the steel occurs due to the water presence in transportation pipelines. This have the tendency to produce a bad internal corrosion, as it has ability to dissolve corrosive gases in this case carbon dioxide. The formation of carbonic acid occurs when carbon dioxide gas dissolve in the water, which result in acid corrosion of carbon steel.

\section{Recommendations}

Some recommendation which may provide better results in the future experimental study

1. Temperature factor: The deposition experiment should be conducted in a hot environment to see the effect of sea environment on the deposition.

2. Residence time factor: Residence time should be included as one of the variables and the experiment conducted in a flow loop which can give a better scenario and accurate result.

3. Sample Orientation: Inversing the sample position in paraffin wax deposition experiment can allow the paraffin wax to deposition faster and more stable. 


\section{References}

[1] Petrowiki.org. (2015). Wax problems in production -[Online]. Available: http://petrowiki.org/Wax_problems_in_production.

[2] Offshore-mag.com. (2015). 'Deepwater Challenges Paraffins: [Online]. Available: http://www.offshoremag.com/articles/print/volume-57/issue-

3/departments/technology-focus/deepwater-challengesparaffins.html.

[3] Simmons, M. (2008). "Oil and Gas "Rust": An Evil Worse Than Depletion", in Offshore Technology Conference (OTC) Presentation, National Association of Corrosion Engineers.

[4] Morales, J. L. Perdomo, J. J. Ramirez, M. and Viloria, A. (2000) "Effect of Crude Oil Contaminants on the Internal Corrosion in Gas Pipelines", CORROSION, paper no. 00040 (Houston, TX: National Association Corrosion Engineers).

[5] Alsabagh, A. M, Migahed, M. A, HayamAwad, S. (2006). Reactivity of polyester aliphatic amine surfactants as corrosion inhibitors for carbon steel in formation water (deep well water), Corrosion Science, 48, 813.

[6] Bentiss, F, Lagrenée M., Traisnel M. (2000). 5-Bis(n-Pyridyl)1,3,4-Oxadiazoles as Corrosion Inhibitors for Mild Steel in Acidic Media, Corrosion, 56, 733. Journal of Corrosion Science, 42, 127.

[7] Deyab, M. A. (2007). Effect of cationic surfactant and inorganic anions on the Electro-chemical behavior of carbon steel in formation water, Journal of Corrosion Science.

[8] Kermani, M. B, Morshed A. (2003). Carbon Dioxide Corrosion in Oil and Gas Production. A Compendium, Corrosion, 59, 659 .

[9] Lebrini, M, Traisnel M, Lagrene M, Mernari B, Bentiss F. (2007). Inhibitive properties, adsorption and a theoretical study of 3,5-bis(n-pyridyl)-4-amino-1,2,4-triazoles as corrosion inhibitors for mild steel in perchloric acid, Journal of Corrosion Science, 50, 473.

[10] Morad, M. S. Kamal, El-Dean A. M. (2006). 2,2'-Dithiobis(3cyano-4,6-dimethylpyridine): A new class of acid corrosion inhibitors for mild steel, Journal Corrosion of Science, 48, 3398 .

[11] Nesic S. (2007). Key issues related to modelling of internal corrosion of oil and gas pipelines-A review', Corrosion Science, volume. 49, 12, 4308-4338.

[12] Reid, R. (1987). The properties of gases and liquids, New York: McGraw-Hill.

[13] Rodriguez-Valdez, L. M, Villamisar W, Casales M, GonzalezRodriguez J. G, Martınez-Villafane A, Martinez L, GlossmanMitnik D. (2006). Computational simulations of the molecular structure and corrosion properties of amidoethyl, aminoethyl and hydroxyethylimidazolines inhibitors, Corrosion Science, 48,4053 .

[14] Shein, A. B., Denisova A. V. (2006). Choice of Effective Corrosion Inhibitors for Acid Treatment of Wells, Protection of Metals, 42, 34 .

[15] Smith, L. (1999). Control of corrosion in oil and gas production tubing, Br. Corrosion Journal, 34 (247).

[16] Villamizar, W. Casales, M. J. Gonzalez-Rodriguez, G. Martinez, L. (2007). $\mathrm{CO}_{2}$ corrosion inhibition by hydroxyethyl, aminoethyl, and amidoethylimidazolines in water-oil mixtures, Journal of Solid State Electrochemistry, 11, 619.

[17] Mohammed, Z. (2007). Industrial and Engineering Chemistry Research, American Conference Institute., 46: 14.

[18] Lund, H. (1998). Investigation of Paraffin Deposition during Single Phase Flow. M S Thesis. The University of Tulsa, Tulsa, OK.

[19] Haq, M. A. (1978). Deposition of Paraffin Wax from Its Solution with Hydrocarbons.

[20] Cole, R and Jessen F. FW. (1960). Paraffin Deposition', Oil Gas Journal, 58, 38-87.

[21] Tang, N. L., Hwu W. L., Chan, R. T., Law, L. K., Fung, L. M. and Zhang, W. M. (2002). A founder mutation (R254X) of SLC22A5 (OCTN2). Hum. Mutat., 20 (3): 232.

[22] Venkatesan, R. (2004). The Deposition and Rheology of Organic Gels, PhD thesis, University of Michigan.

[23] Nazar, I. Tulkun, Y. and Yulduz, D. (2001). Use of and optical sensor (green seeker): an innovative tool for screening germ plasm, predicting biomass and grain yield and management of fertilizer nitrogen, 28.

[24] Jennings, D. W. and Weispfennig, K. (2005). Effect of Shear and Temperature on Wax Deposition: Cold-finger investigation with a Gulf of Mexico Crude Oil, Energy and Fuels, 19, 1376-1386. 